\title{
Marketing Strategies of Ecotourism in Siregar Aek Na Las Village, Toba Samosir
}

\author{
Mariana Simanjuntaka and Santi Agustina Manalu
}

\begin{abstract}
The efforts to develop ecotourism destinations in the area of Lake Toba, as proclaimed by the Government of Indonesia through the Ministry of Maritime Affairs require special awareness and attention for stakeholders including educational institutions in the area of Lake Toba, especially in Toba Samosir. One of the programs developed is the ecotourism of Lake Toba in Siregar Aek Na Las village. The development of ecotourism is expected to become the main national income that is able to expand economic activities, employment, skills and awareness raising local tourism as well as enhance the income of the ecotourism sector. Cultural ecotourism, local wisdom, nature are the recreational and tourism activities that utilize the potential of nature. Siregar Aek Na Las is one of the regencies and tourist destinations in North Sumatera. The potential of Aek Na Las includes nature, hot springs from Lake Toba, cultural arts, customs that belong to local wisdom, the natural landscape of Lake Toba, and other uniqueness. The data collection of this study was obtained from survey, FGD, dissemination and analysis of feasibility study of ecotourism. The analysis shows that the basic development and ecotourism development strategy of Siregar Aek Na Las is focused on improving the quality of service through developing the system initiated by the core committee of Guru Ni Laingan Siregar society throughout Indonesia, raising awareness of local communities, utilizing science and technology, diverse cultures, cemeteries available along the way to Siregar Aek Na Las, weaving, the uniqueness of culinary tourism and especially hot springs from Lake Toba.
\end{abstract}

Index Terms-Ecotourism, segmentation, target market, positioning, marketing strategy.

\section{THE GOAL OF ECOUTORISM MARKETING STRATEGIES IN SIREGAR AEK NA LAS}

Many of the countries are exploring the potential of ecotourism to help them achieve the dual aims of conservation and development. Ecotourism is estimated to be growing at 10 to $15 \%$ per year and contributing US\$154 billion to the world economy [1]. Ecotourism is environmentally responsible travel and visitation to relatively undisturbed natural areas, in order to enjoy and appreciate nature that promotes conservation, has low negative visitor impact, and provides beneficially active socio-economic involvement of local populations. The involvement of the local communities not only benefits the community and the environment but also improves the quality of the tourist experience. Local

Manuscript received April 10, 2019; revised May 1, 2019

The authors are with the Engineering Management, Faculty of Industrial Engineering, Del Institute of Technology, Indonesia (e-mail: anna@del.ac.id). communities can become involved in ecotourism operations and in the provision of knowledge, services, facilities and products. Started from developing world regions, ecotourism offers opportunities for local communities [2].

Marketers argue that a distribution system is the mix of channels used to gain access, or means by which a tourism service is made available to the potential buyers of the product [2]. The failure of ecotourism development is largely due to the lack of awareness and creativity of the community, such as the absence of product diversification, the lack of understanding of the prospects of marketing services by involving others. The other factors are inadequate infrastructure, inability to manage and recognize potentials in the regions, lack of awareness of local ecotourism potential, lack of synergies of cooperation between communities, government and other stakeholders, inability to recognize the trend of people's need for tourism. Quality assurance is needed to create an excellent ecotourism village. Quality of services has become an increasingly significant factor for success and survival in the tourism industry [3]. Aek Na Las ecotourism marketing strategy aims to: (1) optimize the potential of the region as a tourist attraction object, (2) optimize and raise the potential of the village, (3) preserve the art, culture and history, (4) maintain biodiversity and environment of Aek Na Las. Thus, ecotourism activities can increase the welfare of the community (social and economic welfare), ie decreasing unemployment, increasing the willingness of the community to learn and compete positively, improve management skills, such as culinary skills, environmental governance, cultural preservation.

The choice of object marketing is characterized by three attributes: local, unique, and contemporary. It is called local to reduce the huge effort in the preparation of facilities and infrastructure needed. It is called unique, to distinguish the types of tours compared to other areas. This is necessary so that potential tourists want to know more about the uniqueness offered. It is called contemporary to capture the millennial generations which at present is a huge market potential and have more frequent travel habits than previous generations. Based on the 3 (three) characteristics, Siregar Aek $\mathrm{Na}$ Las initiated several types of tourism development. All activities developed do not stand alone, but they are unified in a concept called ecotourism.

Public awareness is the main concern to know, understand, and implement the ecotourism marketing strategy. It is expected not only local officials, business people but also all community groups together with the government, private and education institutions support the strategy implementation. To foster awareness of all parties, there must be an initiating activity which is called Focus Group Discussion (FGD) in the 
area of Siregar Aek Na Las.

\section{Potential Ecoutorism of SiREgar AEK NA LAS VILLAGE}

\section{A. Potential Ecoutorism of Siregar Aek Na Las Village}

Aek $\mathrm{Na}$ Las means warm water, so the village is named Siregar Aek Na Las, because there is warm water from Lake Toba, located on the edge of Lake Toba. Siregar Aek Na Las village is one of the villages in Uluan District, Toba Samosir District, North Sumatra Province, Indonesia. Ecotourism is a resource located in a certain area that can be developed into a tourist attraction. In other words, tourism potential is a variety of resources developed into a tourist attraction utilized for the sake of preservation of local culture, improving economic welfare by paying attention to other aspects such as local wisdom and nature conservation. The attractiveness of ecotourism can attract tourists to visit in a tourist destination, such as: (a) Natural attraction: landscape, seascape, beaches, climate and other geographical features of the destinations. b) Cultural attraction: history and folklore, religion, art and special events, festivals. (c) Social attractions: the way of life, the resident populations, languages, and opportunities for social encounters. (d) Building attraction: building, historic and modern architecture, monument, etc. Working in an institution on the outskirts of Lake Toba and across from the village of Siregar Aek Na Las fosters enthusiasm to develop ecotourism strategies on the outskirts of Lake Toba in Siregar Aek $\mathrm{Na}$ Las. Therefore, the researchers conveyed their interest and discussed with community groups, village heads, migrant groups from Siregar Aek Na Las, the Government of Toba Samosir, especially the Secretary and Head of Tourism Association. The discussion result leads to support mutually the improvement of ecotourism strategy in Siregar Aek Na Las.

In the framework of ecotourism marketing development in Siregar Aek Na Las, FGD has been conducted on January 6, 2018 and April, 2 2018, Sign-ing of mutual understanding between the Institute of Technology Del and Indonesia Siregar Family Community, located in the village of Siregar Aek Na Las. The government of Toba Samosir, community leaders, traditional leaders and observers of the community Siregar Aek Na Las attended in this meeting. The community of Siregar Aek Na Las village expressed a dream to change and introduce the potential and excellence of the village to the national and even international scope, so that society will eventually open to new experiences and jobs. To achieve the collaboration, the main thing to do in line with infrastructure development is promotion and determination of ecotourism village marketing strategy Siregar Aek Na Las.

The aspiration of Siregar Aek Na Las community was also presented in a discussion aimed at providing an enlightenment of marketing and strategy issues to all levels of society including those who live overseas mediated by World Siregar Family Community. All representatives of Siregar Family Unity in Indonesia and overseas also attended in the agreement meeting.

After conducting survey and FGD, the following descriptions were several ecotourism potentials in Siregar
Aek Na Las village:

TABLE I: THE POTENTIAL OF TOURIST OBJECTS IN SIREGAR AEK NA LAS

\begin{tabular}{|c|c|c|}
\hline Tourist Objects & Uniqueness & Strategies \\
\hline $\begin{array}{l}\text { Hot Water from } \\
\text { Lake Toba }\end{array}$ & $\begin{array}{l}\text { Unique, without soda, } \\
\text { hot water right up to the } \\
\text { people's homes }\end{array}$ & $\begin{array}{l}\text { Provision of public } \\
\text { facilities that can enjoy } \\
\text { hot water (Swimming } \\
\text { Pool on the edge of Lake } \\
\text { Toba)* }\end{array}$ \\
\hline $\begin{array}{l}\text { Cemeteries and } \\
\text { History }\end{array}$ & $\begin{array}{l}\text { The uniqueness of the } \\
\text { cemetery lined highly } \\
\text { into the village of Aek } \\
\text { Na Las }\end{array}$ & Need to be polished \\
\hline Weaving Ulos & $\begin{array}{l}\text { Society weave many } \\
\text { ulos (Batak traditional } \\
\text { clothes) }\end{array}$ & $\begin{array}{l}\text { The variations of the } \\
\text { woven clothes }\end{array}$ \\
\hline Culinary & $\begin{array}{lrr}\text { Typical food } & \text { is } \\
\text { available, } & \text { especially } \\
\text { fish from } & \text { Lake Toba } \\
\text { (lobster) } & & \end{array}$ & $\begin{array}{l}\text { Development of taste } \\
\text { and appearance }\end{array}$ \\
\hline Hills & $\begin{array}{l}\text { Along the edge of Lake } \\
\text { Toba, there are various } \\
\text { "thematic" trees }\end{array}$ & $\begin{array}{l}\text { The diversity of plant } \\
\text { species is still small }\end{array}$ \\
\hline Agricultural lands & $\begin{array}{l}\text { Paddy field along the } \\
\text { road to Aek } \mathrm{Na} \text { Las } \\
\text { village }\end{array}$ & $\begin{array}{l}\text { Determination } \\
\text { seasoning } \\
\text { harvest season }\end{array}$ \\
\hline $\begin{array}{l}\text { Art and Culture } \\
\text { Attraction }\end{array}$ & $\begin{array}{l}\text { Many types of cultural } \\
\text { ceremonies; such as } \\
\text { Cultural Ceremonies }\end{array}$ & $\begin{array}{l}\text { Management of art and } \\
\text { cultural attractions, build } \\
\text { art galleries }\end{array}$ \\
\hline Canoe & $\begin{array}{l}\text { Society use the canoes } \\
\text { well }\end{array}$ & $\begin{array}{l}\text { Raising spiritual tours } \\
\text { through canoes praying } \\
\text { in the canoes }\end{array}$ \\
\hline Infrastructure & $\begin{array}{l}\text { The entrance has been } \\
\text { fixed / asphalt }\end{array}$ & $\begin{array}{l}\text { Swimming pool of warm } \\
\text { water, repairmen of } \\
\text { entrance / asphalt, } \\
\text { construction of public } \\
\text { toilets, arrangement of } \\
\text { residents yard }\end{array}$ \\
\hline
\end{tabular}

*The construction of hot spring swimming pools has been held from April 2, 2018, on the edge of Lake Toba Siregar Aek Na Las.

The FGD results show that the list, cluster and dynamics of the mentioned activities are new findings that have become urgent development targets to create ecotourism marketing and invite visitors continuously to Siregar Aek Na Las. These targets increase the dynamics of village needs, and all of them need to be welcomed by the readiness of the community to work and act.

\section{B. Ecoutorism Marketing Strategy}

Organizational theory predicts that the design and strength of the company's internal control environment should be based on the company's business strategy [4]; business strategy deals with how to compete on the markets entered, has also been defined as the competitive weapon of a business, focusing on each unit inside the organization [5]. Marketing capabilities are viewed in terms of a firm's ability to use available resources to perform marketing tasks in ways that achieve desired marketing outcomes, processes that a firm uses to define, develop, communicate, and deliver value to its target customers by combining, transforming, and deploying its available resources [6]. 
Marketing strategy is a unified, comprehensive and integrated set of plans aimed at achieving ecotourism objectives, increasing regional and Indonesian revenues. The following points are the strategies for Siregar Aek Na Las Ecotourism.

TABLE II: ECOUTORISM MARKETING STRATEGy IN SiREGAR AEK NA LAS VILLAGE

\begin{tabular}{lll}
\hline Strategy & Operational Implementation \\
\hline a) Develop short-term goal plans & $\begin{array}{l}\text { The exploration of ecotourism ideas } \\
\text { has been conducted since } 2017 \text { and } \\
2018 .\end{array}$ \\
& & \\
\hline b) Develop long-term plans for & Establishment of local and national \\
ecotourism development, levels of Siregar Association and \\
maintenance and \\
sustainability
\end{tabular}

c) Conduct an analysis of Testing concept, visitor needs ecotourism Siregar Aek Na survey, community readiness in Aek Las, both internal and external Na Las village, environment (SWOT Analysis).

d) Decide the strategy according to the results of analysis as the sustainability of ecotourism marketing program

e) Design a strategy to ensure that goals and objectives that can be achieved through appropriate steps

Determining tourism products, such as agriculture, art and cultura attractions, history, cemeteries, swimming pools, woven clothes.

Improving the infrastructure of Siregar Aek Na Las village entrance, tourism awareness for local people, hot spring promotion, culinary training, English training, restaurant business, home stay/accomodation around Aek Na Las village.

f) Actualize travel activities preparing what is needed in order to carry out the tour.

Regular community assistance for visitor welcoming. Use village development funds for urgent infrastructure development, such as the construction of a hot / warm swimming pool.

e) Prepare the needs of tourists so Reorganize stakeholders they will spend money in the village of Aek Na Las.

The main objective of these strategies is to optimize the things considered as important and urgent as stated by [7] "not everything that counts can count," optimization can be a driving force behind both good and bad marketing performance. The urgent thing is promotional marketing of Aek Na Las Ecotourism. Promotional methods can be free of charge: search engines, directories, discussion lists, forums, chats, banner and link exchange, or pay-per-view: links, sponsorships, banners of all kinds, newsletters etc. The attractiveness of the profile is a major requirement for success, along with the ease of access to the desired information, rule number two being determined by the continuous updating the information posted [8].

\section{Customer Segmentation Siregar Aek Na Las Ecoutorism}

Marketing is a firm's ability to use available resources to perform marketing tasks in ways that achieve desired marketing outcomes, generally viewed in terms of a firm's ability to use available resources to understand and fulfill foreign market customer needs better than its rivals[9]. Marketing optimization requires market segmentation: 'grouping potential customers into sets that are homogeneous in response to some elements of the marketing mix', approaches fall into one of two categories: the a priori or common-sense [10], as "lit markets" consequently harming the overall market quality [11], as performative enhances our knowledge of how theoretical descriptions of marketing approaches shape marketing practice [12].

Visitors can be classified based on the place of ecotourism, including: Benefit Segmentation is focused on prioritized benefits (issues of relaxation, health, halal food, travel comfort, adventure, spiritual tourism, etc.), Demographics; it is based on visitors' age, occupation type, experience, status, income and education), Geographic; it is based on location, country), Psychographic; based on visitors' characteristics (motivation, personality, perception, interests and life values), Multilevel; it is based on some combination as previously mentioned. The usefulness of segmentation provides benefits to the visitor's needs, the application of the strategy to the visitor's needs obtaining a higher precision.

The process of classification starts from: (1) market segmentation as a messy, pragmatic and iterative accomplishment is described, which extends existing knowledge of how this important and costly process is realised; (2) framing market segmentation as performative allows us to draw insight into how the segmenting of a market shapes and is shaped by practices [12]. To facilitate grouping, some activities are implemented such as group surveys, factor analysis on a number of data, dominant profiles creation and market targets.

\section{Market Segmentation Evaluation of Siregar Aek $\mathrm{Na}$ Las Ecoutorism}

The objective assessment states that Aek $\mathrm{Na}$ Las ecotourism can be used as a business model, namely: (1) Development of ecotourism market segment focused on the beauty of Lake Toba, with special uniqueness hot water found from Lake Toba and not in the form of sulfur. The realization can be seen from the existence of hot waterpool. (April 2, 2018) operated in July 2018. Hot water of Lake Toba in Aek $\mathrm{Na}$ Las set as a tourist model in Aek Na Las. (2) Utilization of the lake situation, with the existing equipment in the lake such as a canoe that can be used as spiritual tourism by praying in that canoe. (3) The entrepreneurial segment is also a finding in Aek $\mathrm{Na}$ Las, ie many ulos weavers empowered as traditional cloth observers can create the histories of 'ulos' (woven clothes). (4) Parallel hills can be used as agro-tourism by grouping "thematic" plants in every hill, for example the distinction and grouping between durian, citrus, coffee and tea, tea local plants that reflect local wisdom.

To attract the customers (tourists) come to Aek Na Las, it is necessary to improve the service, hospitality, tourism management, in cooperation with the existing tourism owners around Toba Samosir. In other words, the strategies make a tourist map that attracts visitors stay 4-5 days in Toba Samosir. The other things needed are the training and creation of art and cultural attraction groups, such as dances with various themes including customs / symbols of birth, marriage and 
death, history and the origin of "dalihan natolu/three stoves".

\section{POSITIONING IN ECOUTORISM SIREGAR AEK NA LAS}

Positioning is a strategy in marketing activities that aims to create differences, advantages, benefits, expectations that make visitors always remember the uniqueness of an ecotourism village. According to [13] Positioning is a fundamental-marketing strategy particularly for a new product or innovative product. Innovative product has a positive influence to product positioning quality. It is in line with [14] stating that firms as actors in business networks have intentions, interpret the surrounding context and take strategic action with respect to the positioning of the firm. [15] describes that positioning is influential in the process of communication; and regarded as a key tool for brand implementation in competitive market [16].

When viewed as an ecotourism industry, the entrepreneurs need to maintain ideas, good memories and invite tourists to visit again and invite others to participate. Basically, visitors will come back and keep good memories in the ecotourism village, when they get easy information (road guide, location/map information, transportation, available food, drink and shelter, comfort until leaving the village of ecotourism, the availability of various local wisdom (attraction, souvenirs) and the involvement of visitors to participate directly in the available activities.

This is to say that the company must map the value, so that the product positioning is not what can be done to the product and service, but beyond it, what can be done to the target consumer consistently. The other things needed are placement modification, and monitoring consumers' perception to an object being marketed.

What is being done in Aek Na Las is to create the uniqueness on ecotourism products, one of the examples is cultural tourism with selected Cultural Ceremonies (Mangongkal Holi, which is a Batak tradition to honor ancestors by digging and lifting the bones of the ancestors to be placed on the monument, praying before spreading fish net in the Lake, 'tortor' which is a Bataknese attraction dance). The choice of cultural ceremonies to be deployed will be designed and defined a year before implementation The preparation including the socialization through various media, determining the price of the product attraction, engaging the visitor to play a role in the attraction, establishing cultural attractions, extending the promotion and packaging a tour package.

\section{IMPLEMENTATION OF MARKETING STRATEGY IN SIREGAR AEK NA LAS}

To achieve the objective of ecotourism marketing strategy in Aek $\mathrm{Na}$ Las village, it is necessary to implement all planning, reimplementation and evaluation. According to [6], the stages of implementation strategy start from: 1) Plan media that overlap broad and narrow targets, 2) Activate unexposed audiences on television via digital, 3) Measure unduplicated reach across platforms for broad and narrow audience targets, 4) Measure brand lift and sales lift for the same campaigns. In other words, the development of ecotourism environment management, also simultaneously provides promotional tools for the sale of ecotourism products. Promotion ensures that the targeted community is informed about what is available in the ecotourism village and how to achieve it. Promotion is also in line with what [17] states that companies can also access a consumer's location using cell tower signal-based technologies, Wi-Fi Internet access point technology, or crowd-sourced positioning.

Implementation such as information publishing by building ecotourism information system is conducted through social media, road guide and travel agency to facilitate accessibility to Siregar Aek Na Las village. When information has been delivered to the target visitors, their activities and needs are also available such as swimming pools, welcoming from local people, the available culinary variety, travel agency information, guiding.

The other strategy is to create some tourism products in a package, as described by [18] the tourist' decision regarding the destination, optimum period for the trip and the touristic agency which can mediate the voyage, is being influenced by the recommendations and information usually subjective of the persons from his company (social channels) which have "experimented" the respective touristic services. At this point, there comes also the information obtained from the touristic units (voyage agencies, hospitality structures, touristic offices), expert channels (opinion starters, recommendations), also through impersonal communicational media (media," atmosphere" and " events").

Tourist attraction is the terminal of travel mobility. Therefore, it must meet all the special mobility determinants of accommodation. The current implementation in this village is homestay construction at Aek Na Las (first stone laying, April 2, 2018) along with the construction of the hot spring swimming pools. The attractions available in Aek Na Las should be able to hold visitors stay in a long period and the impression presented to visitors should last long. Every visitor who has memories at Aek Na Las will tell others and invite others to visit again.

In addition to the previous explanation, it is also necessary to pay attention to how to set the layout perspective, the arrangement of the entrance, arrangement of colors, like the color of cemetery buildings to Aek Na Las, to create a story about Aek Na Las which is delivered to the visitors through brochures, leaflets, booklets. Lastly, accessibility is a main requirement for ecotourism management in Siregar Aek Na Las including accessibility to information, transportation, accommodation and travel bureau.

Finally, the managerial implementation which is more of a long-term commitment and stakeholder team collaboration (collaborative management) of the Aek $\mathrm{Na}$ Las village ecotourism developer brings positive impacts and attracts more visitors. Community-based ecotourism that takes the dimension of ecotourism business using the concept of co-management is one of the ways to increase community participation where local communities are directly involved starting from the stages of planning, implementation, monitoring and evaluation. Society is the main key for 
ecotourism business.

\section{CONCLUSION}

The marketing strategies of Aek Na Las ecotourism can be implemented through 1) the cooperation between the community, the group of Siregar Community, Local Government, Del Institute of Technology (IT Del), 2) sustainability commitment, by presenting the objects of Lake Toba, hot springs, the history of Batak, which are packed again in the cultural attractions, 'ulos' as traditional woven clothes, spiritual attractions (eg praying rituals in Lake Toba using a canoe, culinary, natural and beautiful hills that are entirely incorporated in a unified tour package suitable to visitors.

Tour packages should vary, attract, and store cultural values, history, local wisdom which indirectly will improve the economy of society, welfare, desire to learn and serve, enhance the pride of the area Aek $\mathrm{Na}$ Las and create a new impression for tourist especially foreign countries that the beatiful place in Indonesia is not just in Bali.

\section{REFERENCES}

[1] E. Gabriel and D. E. Tagoe, "Ecotourism development in Ghana: A postcolonial analysis," Development Southern Africa, 2015.

[2] M. Etienne and W. Michael, "Assessment of marketing strategies for ecotourism promotion: A case of RDB/tourism and conservation in rwanda," Journal of Marketing Development and Competitiveness, vol. 7, no. 2, 2013.

[3] S. Nitasha, "Developing and validating an instrument for measuring online service quality in the tourism sector," Journal of Management Research, vol. 17, no. 1, 2018.

[4] G. Kathleen, A. Bentley, N. J. Nathan, and A. M. Thompson, "Business strategy, internal control over financial reporting, and audit reporting quality," Journal of Practice and Theory, vol. 36, no. 4, 2017.

[5] A. Dianwicaksih, S. Utama, and R. Wardhani, "Environmental uncertainty as a contingent factor of business strategy decisions: Introducing an alternative measure of uncertainty,"AABFJ Volume, vol. 11 , no. $4,2017$.

[6] M. A. Neil, C. S. Katsikeas, and D. W. Vorhies, "Export marketing strategy implementation, export marketing capabilities, and export venture performance," Journal of the Academy of Marketing Science, vol. 40, no. 2, pp. 271-89, 2012.

[7] M. F. Gian, "Are you targeting too much? effective marketing strategies for brands," Journal of Advertising Research, 2017.
[8] M. Seracin, I. Iosim, D. O. Manuela, "Promoting agrotourism through social media," Agricultural Management/Lucrari Stiintifice Seria I. Management Agricol, vol. 19, no. 3, pp. 189-192, 2017.

[9] A. M. Neil, H. Feng, and K. A. Whitler, "Marketing capabilities in international marketing," Journal of International Marketing, vol. 26, no. 1, 2018, pp. 61-95, 2018.

[10] S. Dolnicar and F. Leisch, "Using graphical statistics to better understand market segmentation solutions," International Journal of Market Research, vol. 56, no. 2, 2013.

[11] F. Hatheway, A. Kwan, and H. Zheng, "An empirical analysis of market segmentation on U.S. equity markets," Journal of Financial and Quantitative Analysis, vol. 52, no. 6, pp. 2399-2427, 2017.

[12] P. Venter, A. Wright, and S. Dibb, "Performing market segmentation: A performative perspective," Journal of Marketing Management, vol. 31, no. 1-2, pp. 62-83, 2015

[13] H. Syamsier, "The mediating role of product positioning quality and product attractiveness advantage," International Journal of Business and Management Science, vol. 7, no. 1, pp. 1-10, 2016.

[14] S. S. Laari, "Strategic practices of subsidiary positioning in business networks," 2018

[15] C. Blankson, S. Ketron, S. Coffie, "Positioning strategies by foreign retailers at the accra mall in ghana: A case study approach," Journal of Managerial Issues, vol. 29, no. 3, 2017.

[16] W. H. Ju, "A new approach to network analysis for brand positioning," International Journal of Market Research, vol. 57, pp. 727-742, 2015.

[17] D. A. Basil, "Global positioning systems and social media-anathemas to privacy," Defense Counsel Journal, 2017.

[18] N. Al. Mircea, "Romanian tourism promotion," The USV Annals of Economics and Public Administration, vol. 17, no. 2, 2017.

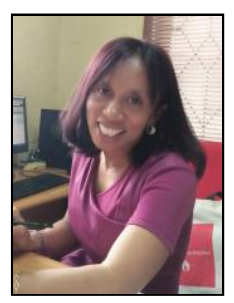

Mariana Simanjuntak as the first author was born in Sigumpar, in 1974. She currently works in Institut Teknologi Del as a lecturer of Engineering Management. She is interested in conducting the studies majoring in business process, knowledge management, ecoutorurism, supply chain, industrial management, marketing and Cha RACTER building.

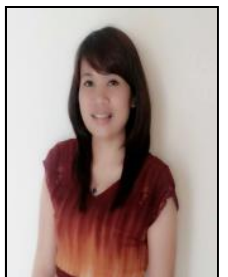

Santi Manalu was born in Tarutung, in 1983. She has been teaching in Institut Teknologi Del for 5 years. Her research interest is knowledge management, strategic management, marketing and lang, and language studies. 